\title{
Mikrokontroler Sistem Komunikasi Sensor Jamak Menggunakan Serial Rs-485 Multi Processor Communication
}

\author{
Kadek S Wibawa ${ }^{\mathrm{a} 1}$, A.A.K. O Sudana ${ }^{\mathrm{a} 2}$, Putu W Buana ${ }^{\mathrm{a}}$ \\ aJurusan Teknologi Informasi, Fakultas Teknik, Universitas Udayana \\ Jalan Kampus Bukit Universitas Udayana, Bali, Indonesia \\ ${ }^{1}$ suar wibawa@yahoo.com \\ 2agungokas@hotmail.com \\ 3wbhuana@gmail.com
}

\begin{abstract}
Abstrak
Sistem komunikasi sensor jamak menggunakan standar komunikasi RS-485 untuk menghubungkan tiap pemroses data berbasiskan mikrokontroler membentuk jaringan topologi BUS. Sistem komunikasi ini memiliki kunggulan dalam hal: konektivitas (mudah dalam melakukan koneksi tiap node pada jaringan komunikasi), skalabilitas (tingkat fleksibilitas yang tinggi dalam perluasan jaringan), tahan terhadap derau dan mudah dalam melakukan perawatan/perbaikan jaringan. Sistem komunikasi sensor jamak, dibangun menggunakan pendekatan model komunikasi master-slave. Sistem komunikasi master-slave yang dikembangkan menggunakan topologi jaringan BUS perlu menerapkan filter terhadap lalulintas paket data pada saluran komunikasi. Setiap node yang terhubung pada jaringan komunikasi menggunakan topologi BUS mampu mendengar setiap paket data yang lewat pada jaringan tersebut. Multi Processor Communication (MPC) mode dapat diterapkan untuk mengurangi beban kerja prosesor didalam memeriksa tiap paket data yang lewat. Prosesor yang bekerja pada sisi slave hanya perlu memeriksa pesan yang ditujukan sesuai dengan alamatnya tanpa perlu memeriksa setiap paket data yang lewat dalam saluran komunikasi.
\end{abstract}

Kata kunci: Multi Processor Communication (MPC), Monitoring system, RS-485.

\begin{abstract}
Multi-sensor communication system uses RS-485 standard communication connecting each microcontroller-based data processing unit to form BUS topology network. The advantages of this communication system are: connectivity (easy to connecting devices on a network), scalability (flexibility to expand the network), more resistant to noise, and easier maintenance. The System is built using Master-Slave communication approach model. This system need to filter every data packet on communication channel because every device that connect in this network can hear every data packet across this network. Multi Processor Communication (MPC) model is applied to reduce processor's burden in inspecting every data packet, so the processor that work in slave side only need to inspect the message for itself without inspecting every data packet across the communication chanel.
\end{abstract}

Keywords: Multi Processor Communication (MPC), Monitoring system, RS-485.

\section{Pendahuluan}

Sistem komunikasi melibatkan lebih dari satu perangkat pemroses data yang terhubung dengan sensor untuk melakukan pengamatan terhadap suatu objek sudah menjadi tren saat ini. Perkembangan sistem jaringan komunikasi seperti ini harus mampu memenuhi kebutuhan multi-poin [1] untuk menyediakan terminal bagi tiap perangkat terhubung ke dalam sistem jaringan yang dibentuk. Sistem minitroing [2] dan sistem telekontrol SCADA [2] menggunakan sistem komunikasi multi-poin serial RS485 [3] untuk menghubungkan tiap perangkat kedalam sistem jaringan menggunakan pendekatan model topologi jaringan BUS. 
Topologi Jaringan BUS pada serial komunikasi RS-485 memiliki beberapa keunggulan diantaranya: (1) mudah dalam melakukan konektivitas terutama untuk penempatan sensor jamak yang membutuhkan interkoneksi antar perangkat yang terhubung dalam jaringan pada jarak yang berjauhan; (2) mudah dalam melakukan perluasan jaringan; (3) biaya yang murah. Data yang ditransmisikan pada serial komunikasi RS-485 dibentuk kedalam paket data [4].

Paket data pada sistem komunikasi BUS ditransmisikan secara broadcasting sehingga setiap perangkat yang terhubung kedalam jalur komunikasi dapat mendengar setiap paket data yang lewat. Semakin tinggi tingkat lalulintas data pada jaringan komunikasi, maka akan semakin tinggi juga tingkat kinerja prosesor yang dibutuhkan untuk memeriksa setiap paket data yang lewat. Beban kerja prosesor dapat dikurangi dengan menggunakan mekanisme untuk melakukan filter dan kategori paket yang dikirim pada saluran komunikasi.

\subsection{Metodologi Penelitian}

\subsection{Tahapan Penelitian}

Penelitian dibagi kedalam 3 tahap yaitu: Rancangan sistem, Implementasi sistem dan Pengujian sistem. Lokasi penelitian dilakukan pada Laboratorium Jurusan Teknologi Informasi Kampus Bukit Jimbaran.

\subsection{Rancangan model penelitian}

Rancangan model penelitian dibagi menjadi dua sub bagian yaitu : (1) rancangan perangkat keras dan jaringan komunikasi; (2) rancangan perangkat lunak.

a. Rancangan Perangkat Keras

Diagram umum sistem pada sistem komunikasi multi poin untuk sensor jamak dapat dilihat pada Gambar 1.

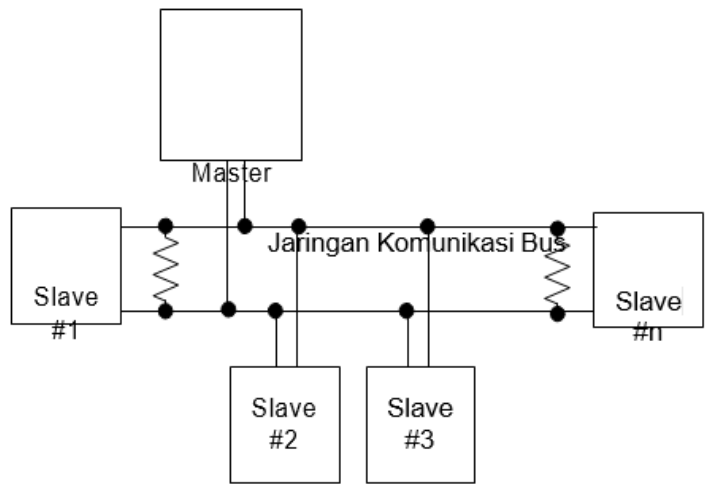

Gambar 1. Diagram umum sistem komunikasi sensor jamak

Sistem komunikasi multi point untuk sensor jamak menggunakan serial komunikasi RS485 sebagai antarmuka sistem komunikasi. Setiap piranti terhubung ke dalam jaringan komunikasi melalui sebuah terminal, membentuk topologi jaringan BUS.

Piranti perangkat keras dibangun menggunakan mikrokontroler sebagai main processing dan masing-masing piranti dilengkapi dengan antar muka MAX-485 sebagai komponen sistem komunikasi data. Piranti perangkat keras dibedakan menjadi dua bagian yaitu: Piranti perangkat keras Master dan piranti perangkat keras Slave. Spesifikasi teknis rancangan perangkat keras seperti terlihat pada tabel 1 [5].

Desain Perangkat Keras dibedakan kedalam tiga kategori sesuai dengan fungsinya yaitu: Perangkat Keras Master, Perangkat Keras Slave \#1 (disertakan sensor RHT untuk mengukur temperatur dan kelembaban relatif) dan Prangkat Keras Slave \#2 (disertakan sensor GPS). 


\section{b. Rancangan Perangkat Lunak}

Perangkat lunak dikembangkan menerapkan sintak kode bahasa pemrograman $\mathrm{C}$ pada chip programable mikrokontroler embedded system. Seperti halnya pada perangkat keras, sistem perangkat lunak dikembangkan menjadi dua bagian yaitu sistem perangkat lunak Master dan sistem perangkat lunak Slave seperti terlihat pada gambar 2[6].

Tabel 1. Spesifikasi Perangkat Keras

\section{Master Board}

\begin{tabular}{|c|c|c|c|}
\hline$\overline{\text { No. }}$ & Komponen & Spesifikasi & Fungsi \\
\hline 1 & Mikrokontroler & $\begin{array}{l}32 K \text { Bytes Flash program } \\
\text { memory, } 16 \text {-bit } \\
\text { timer/Counter,Programmable } \\
\text { Serial USART. }\end{array}$ & Unit pemroses data \\
\hline 2 & MAX-485 & $\begin{array}{l}32 \text { multi drop, differential } \\
\text { signal, 5volt DC Source }\end{array}$ & Antar muka komunikasi serial BUS \\
\hline 3 & LCD Grafic & $\begin{array}{l}128 \times 64 \text { dot matrix with led } \\
\text { back light }\end{array}$ & $\begin{array}{l}\text { Tampilan untuk antar muka } \\
\text { pengguna akhir }\end{array}$ \\
\hline 4 & Komponen pendukung lain & Sesuai kebutuhan & Komponen utama /pelengkap \\
\hline
\end{tabular}

\begin{tabular}{|c|c|c|c|}
\hline \multicolumn{4}{|c|}{ Slave Board } \\
\hline 1 & Mikrokontroler & $\begin{array}{ll}8,16, \quad 32 K \text { Bytes } & \text { Flash } \\
\text { program memory, } & 16 \text {-bit } \\
\text { Timer/Counter, } & \\
\text { Programmable } & \text { Serial } \\
\text { USART. } & \end{array}$ & Unit pemroses data \\
\hline 2 & MAX-485 & $\begin{array}{l}32 \text { multi drop, differential } \\
\text { signal, 5volt DC Source }\end{array}$ & Antar muka komunikasi serial BUS \\
\hline 3 & LCD & $\begin{array}{l}8 \times 2 \text { dot matrix with led } \\
\text { back light }\end{array}$ & $\begin{array}{l}\text { Tampilan untuk antar muka } \\
\text { pengguna }\end{array}$ \\
\hline 4 & Sensor & Sesuai kebutuhan & $\begin{array}{l}\text { Sebagai media uji untuk proses } \\
\text { pengukuran }\end{array}$ \\
\hline 5 & $\begin{array}{l}\text { Komponen } \\
\text { pendukung lain }\end{array}$ & Sesuai kebutuhan & Komponen utama /pelengkap \\
\hline
\end{tabular}

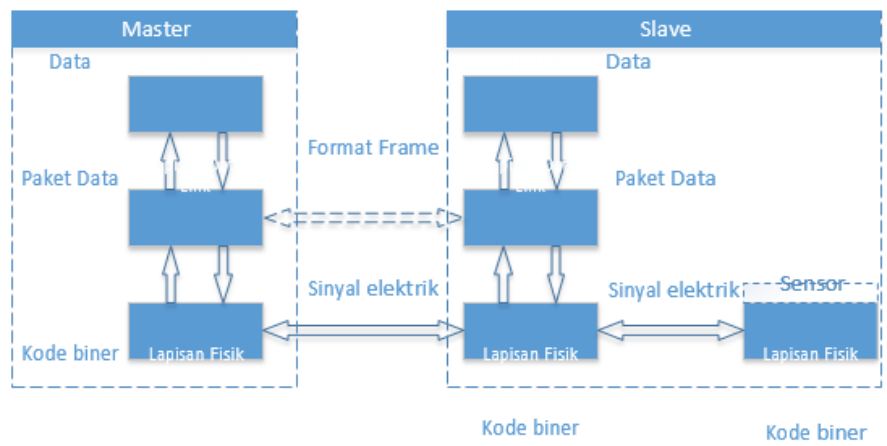

Gambar 2. Lapisan Perangkat Lunak 
Perangkat lunak Master memiliki fungsi dan tanggung jawab:

- Melakukan kontrol dan manajemen sistem komunikasi data.

- Menampung data sementara dan mengolah data dari slave menjadi bentuk informasi.

- Berfungsi sebagai antarmuka sistem dengan pengguna akhir, memberikan informasi tampilan visual kepada pengguna.

Perangkat lunak Slave didesain bersifat pasif, hanya bekerja jika diperintahkan. Jika tugas yang diberikan telah selesai dikerjakan maka slave berada pada mode sleep. Perangkat lunak slave memiliki fungsi:

- Melakukan pengukuran dan mengolah data hasil ukur sensor.

- Menyediakan data hasil ukur yang diperlukan oleh Master.

Slave berinteraksi dengan sensor melalui antarmuka sistem komunikasi yang disediakan untuk melakukan proses ukur dan mengolah data hasil ukur yang diterima oleh sensor.

\section{Kajian Pustaka}

\subsection{Sistem Komunikasi data}

dalam jaringan komunikasi. Pada sistem komunikasi terdapat tiga elemen dasar untuk melakukan proses Komunikasi data merupakan proses pengiriman dan penerimaan data/informasi dari dua atau lebih piranti yang terhubung komunikasi, tiga elemen tersebut adalah: Sumber Data (Source); Media transmisi dan Penerima (Receiver), seperti yang terlihat pada Gambar 3. Prinsip dasar sistem komunikasi data.

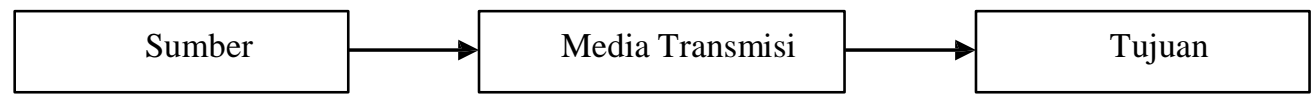

Gambar 3. Prinsip dasar sistem komunikasi data

Pada Sistem komunikasi data umumnya dikenal dua pendekatan cara pengiriman data yaitu pengiriman data secara paralel dan serial. Suatu pengiriman data disebut paralel jika sekelompok bit data ditransmisikan pada waktu yang sama dan menggunakan beberapa jalur transmisi. Disebut serial jika data ditransmisikan bit per bit untuk setiap bit data secara berurutan pada satu jalur komunikasi yang sama. Melihat Arah aliran data pada sistem komunikasi serial maka dapat dikelompokan menjadi tiga model cara berkomunikasi: (1) Simplex; (2) Duplex dan (3) Halfduplex. Dengan mengikuti model dan aturan cara berkomunikasi, setiap node (piranti) yang terhubung dalam jaringan komputer (membentuk topologi mesh, star, ring, dan Bus) dapat berbagi data atau sumber daya yang ada.

\subsection{Mode Multi Processor Communication (MPC)}

Multi Processor Communication (MPC) merupakan fitur mode komunikasi yang dimiliki oleh serial UART mikrokontoler. Mode ini menggunakan teknik pengalamatan dengan memanfaatkan 1 bit data terakhir untuk mengindikasikan bahwa paket tersebut berupa frame alamat atau frame data, seperti yang terlihat pada Gambar 4. Struktur Bit pada Mode MPC.

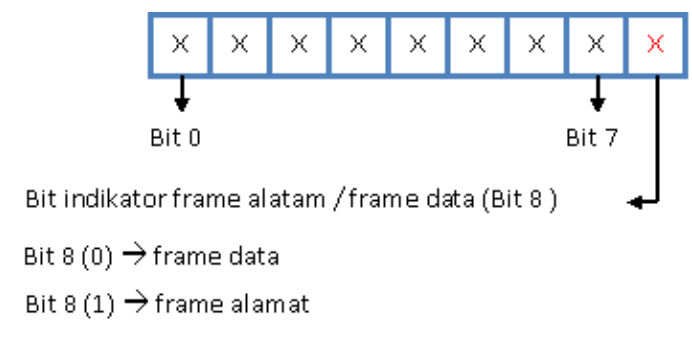

Gambar 4. Struktur bit pada MPC 
Mode komunikasi MPC mampu memberikan pengalamatan hingga 256 (8 bit). Berikut merupakan fitur dari MPCM serial UART.

- Mengatur MPCM bit di UCSRnA memungkinkan fungsi memfilter frame masuk yang diterima oleh receiver USART.

- Frame yang tidak mengandung informasi alamat akan diabaikan dan tidak di masukkan ke dalam buffer penerima. Hal Ini secara efektif mapu mengurangi jumlah frame masuk yang harus ditangani oleh CPU, dalam sistem dengan beberapa mikrokontroler yang berkomunikasi melalui serial bus yang sama.

- Transmiter tidak terpengaruh oleh pengaturan MPCM ini, namun harus digunakan berbeda ketika bagian dari sistem memanfaatkan mode komunikasi multi-prosesor tasking.

\section{Hasil dan Pembahasan}

\subsection{Hasil Rancangan Perangkat Keras}

Hasil rancangan model perangkat keras seperti terlihat pada Gambar 5. Gambar 5 a) merupakan rancangan model perangkat keras Master, Perangkat keras Master berfungsi sebagai unit koleksi data dan antarmuka dengan pengguna akhir, menyajikan parameter hasil ukur berupa data/informasi dalam bentuk tampilan $L C D$ grafis $128 \times 64$ dot matrix.

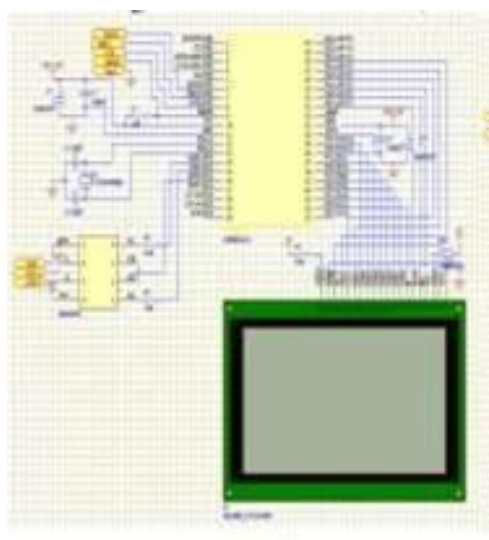

a)

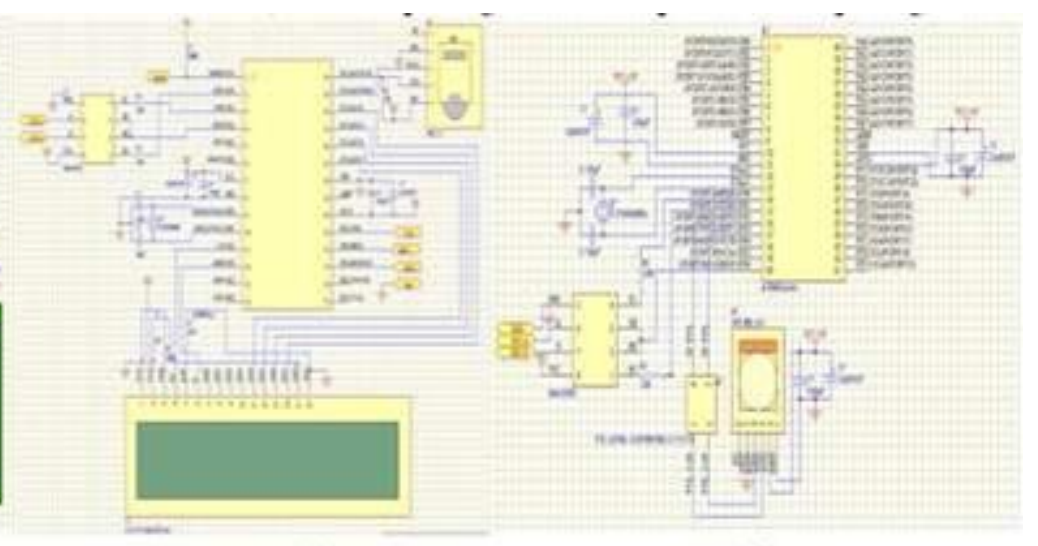

b)

c)
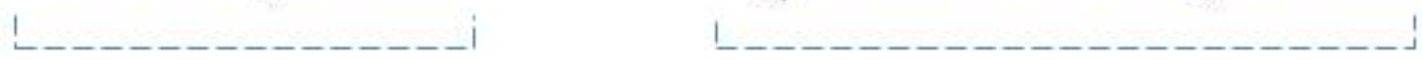

Kode biner

Kode biner

Gambar 5. Rancangan Perangkat Keras a) Perangkat Keras Master, b) Perangkat Slave \#1, c) Perangkat Slave \#2

Gambar 5 b) merupakan rancangan model perangkat keras Slave \#1. Piranti slave \#1 dihubungkan dengan sensor temperature and relative humidity mengunakan saluran komunikasi I2C. Untuk melihat hasil ukur sensor pada piranti ini dilengkapi $L C D$ dot matrix $2 \times 8$ yang menampilkan hasil ukur temperatur dalam ${ }^{\circ} \mathrm{C}$ dan kelembaban relatif dalam \%. Diagram skematik Slave \#1, Gambar 5 c) merupakan rancangan model perangkat keras Slave \#2. Piranti Slave \#2 dihubungkan dengan sensor GPS untuk melalukan pengukuran koordinat posisi berupa latitude dan longitude dan update waktu jam, menit, detik yang didapat dari clock receiver GPS.

\subsection{Hasil Rancangan Perangkat Lunak}

Master memberikan perintah kepada slave dalam bentuk pesan alamat (address). Pesan tersebut di-generate pada interval waktu $25 \mathrm{mS}$ memanfaatkan fungsi interrupt timer tiap satu detik. Selama satu detik Master mampu mengenerate sebanyak 40 pesan secara berulang. State diagram perangkat lunak Master seperti terlihat pada Gambar 6 [7]. 


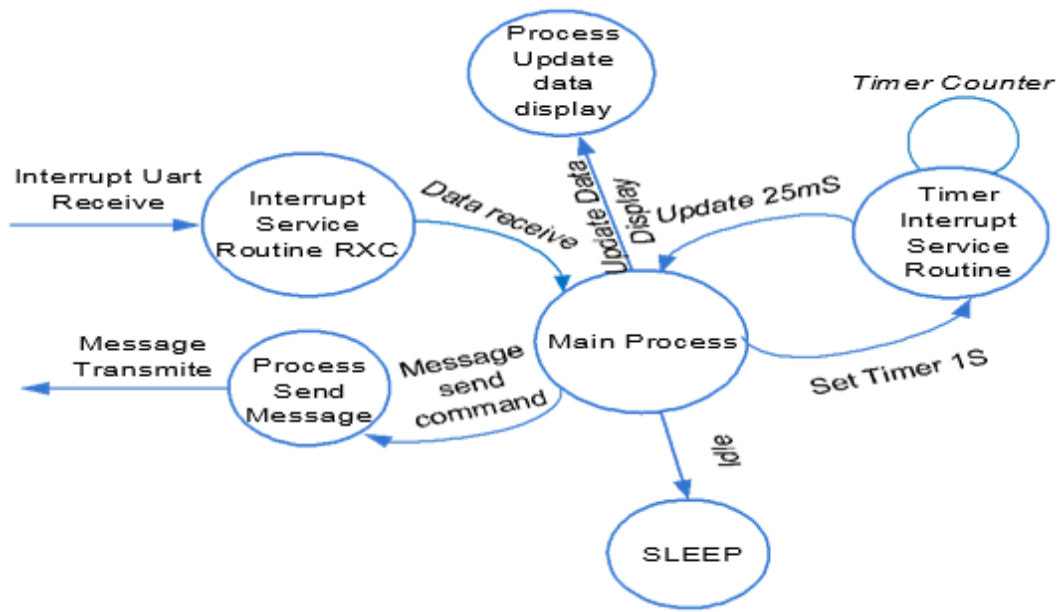

Gambar 6. Rancangan Perangkat Lunak Master

Mode Multi Processor Communication (MPC) membedakan pesan menjadi dua bagian yaitu pesan berupa alamat dan pesan berupa data. Skema MPC pada Master men-generate pesan berupa alamat yang nantinya diterjemahkan oleh slave menjadi kode perintah. Desain skema diagram proses pengiriman pesan dengan menggunakan mode MPC seperti terlihat pada Gambar 7 .

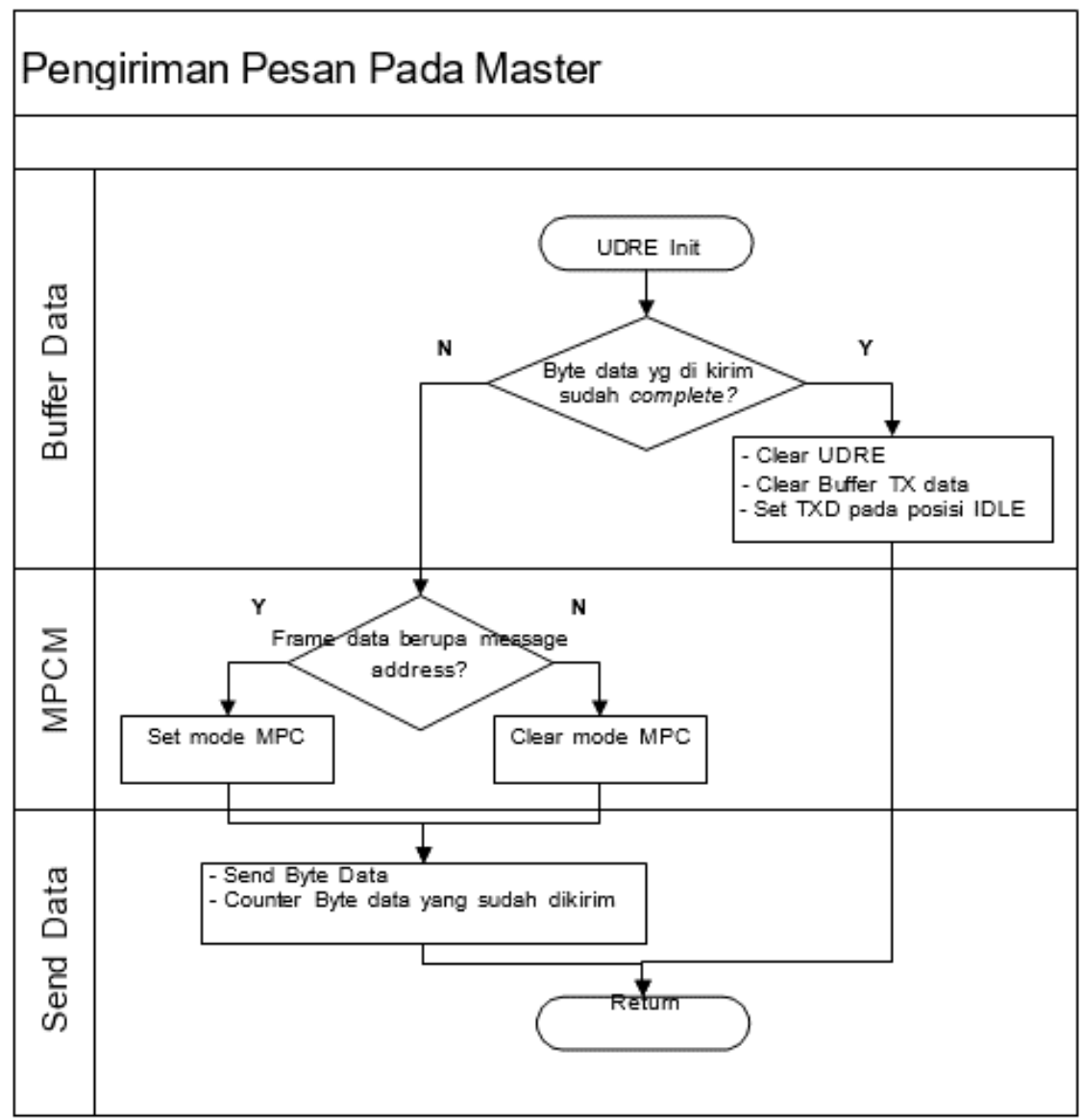

Gambar 7. Proses pengiriman pesan menggunakan MPC pada Master 
Slave berinteraksi dengan sensor melalui antarmuka sistem komunikasi yang disediakan untuk melakukan proses ukur dan mengolah data hasil ukur yang diterima oleh sensor. Proses ini dilakukan jika terdapat pesan yang diberikan oleh master berupa pesan alamat yang menyatakan bahwa sensor malakukan pengukuran secara serentak (broadcast).

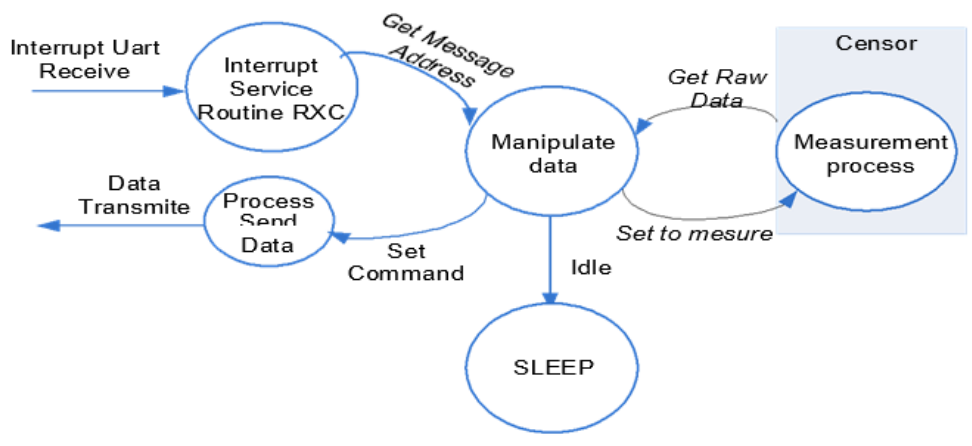

Gambar 8. State diagram perangkat lunak Slave

Nilai hasil olah data ini disimpan sementara pada buffer hingga slave mendapatkan perintah pesan alamat oleh master untuk mengirimkan data hasil ukur sensor pada selang waktu berikutnya. Secara default Slave berada pada kondisi IDEL jika tugas yang diberikan oleh master telah selesai dikerjakan slave masuk dalam mode SLEEP. State diagram perangkat lunak Slave seperti terlihat pada Gambar 8. Proses pengiriman data pada slave menggunakan mode clear mode MPC karna slave hanya mengirimkan data kepada master dan tidak melakukan komunikasi dengan slave yang lain. Desain skema diagram proses pengiriman data pada slave seperti terlihat pada Gambar 9.

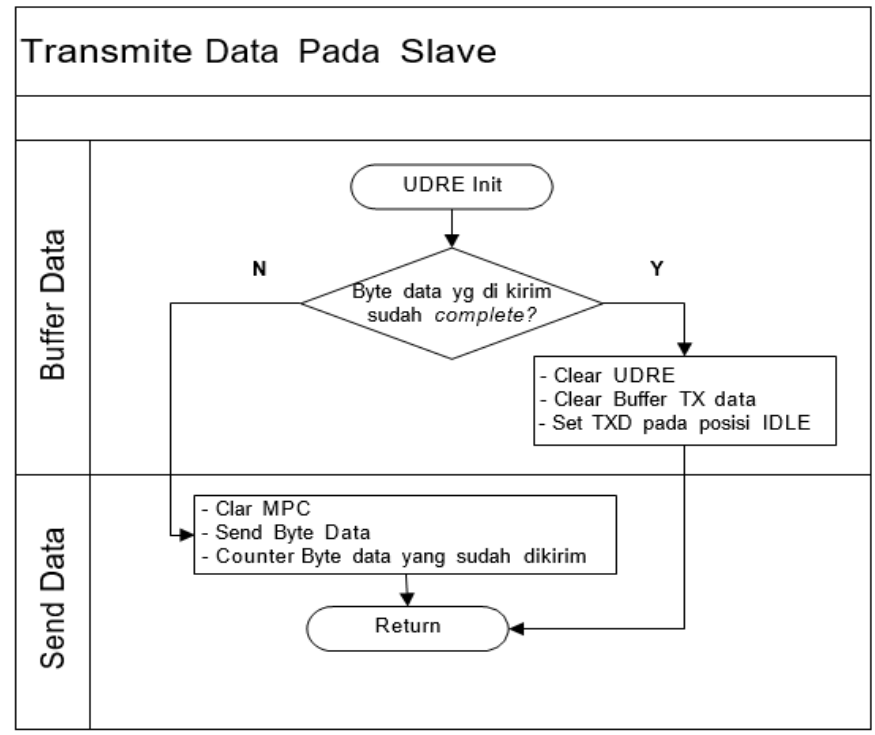

Gambar 9. Proses pengiriman Data pada Slave

Pada desain ini, tiap piranti memiliki alamat unik yang menyatakan identitas masing-masing piranti. Tiap Slave mengirimkan data yang dibutuhkan oleh master sesuai dengan pesan alamat yang diterima. Untuk mengidentifikasi dan menjamin keabsahan data yang dikirimkan oleh slave maka data dikirim dalam bentuk paket data menggunakan format frame seperti pada Gambar 10 pada lapisan datalink dengan menyertakan checsum sebagai mekanisme validasi data. 


\begin{tabular}{|l|l|l|l|l|l|l|l|}
\hline Start Bit & Jml & Tujuan & Sumber & Perintah & nByte Data & Checksum & Stop Bit \\
\hline
\end{tabular}

Gambar 10. Format Frame Data pada Data Link Layer

Keterangan :

Start bit

Jumlah

Sumber

Tujuan

Command

nByte data

Checksum

Stop bit
: Awal data

: Jumlah merupakan panjang payload data (1 byte)

: ID dari sumber data ( 1 byte)

: ID dari sumber data (1 byte)

: Respon data untuk nomor alamat yang diberikan oleh Master ( 1 byte)

: Data payload ( $\mathrm{n}$ byte data)

: Koreksi data error (1 byte)

: Akhir dari data

\subsection{Pembahasan}

Pada mode MPC format data serial menggunakan pengaturan 9 bit data dimana data terakhir pada register data bit 8 (dari bit $0 \mathrm{~s} / \mathrm{d}$ bit 8 ) mengindikasikan bahwa frame tersebut berupa data atau berupa alamat perintah seperti yang telah dijelaskan pada point 4.2, list kode program untuk setup register tersebut seperti pada Gambar 11 .

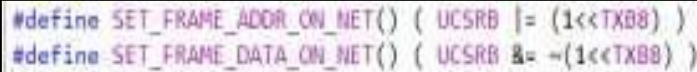

Gambar 11. List Kode Program Pengaturan Mode MPC berupa Frame Data atau Alamat

Baris pertama kode program menunjukan bahwa frame yang dikirimkan Piranti Master melalui BUS serial line berupa alamat dimana pada register UCSRB untuk bit 8 (bit terakhir mode 9 bit) diset dengan nilai 1 . Baris kedua kode program merupakan frame berupa data dimana pada format ini, nilai register UCSRB untuk bit register TX8B diset dengan nilai 0 .

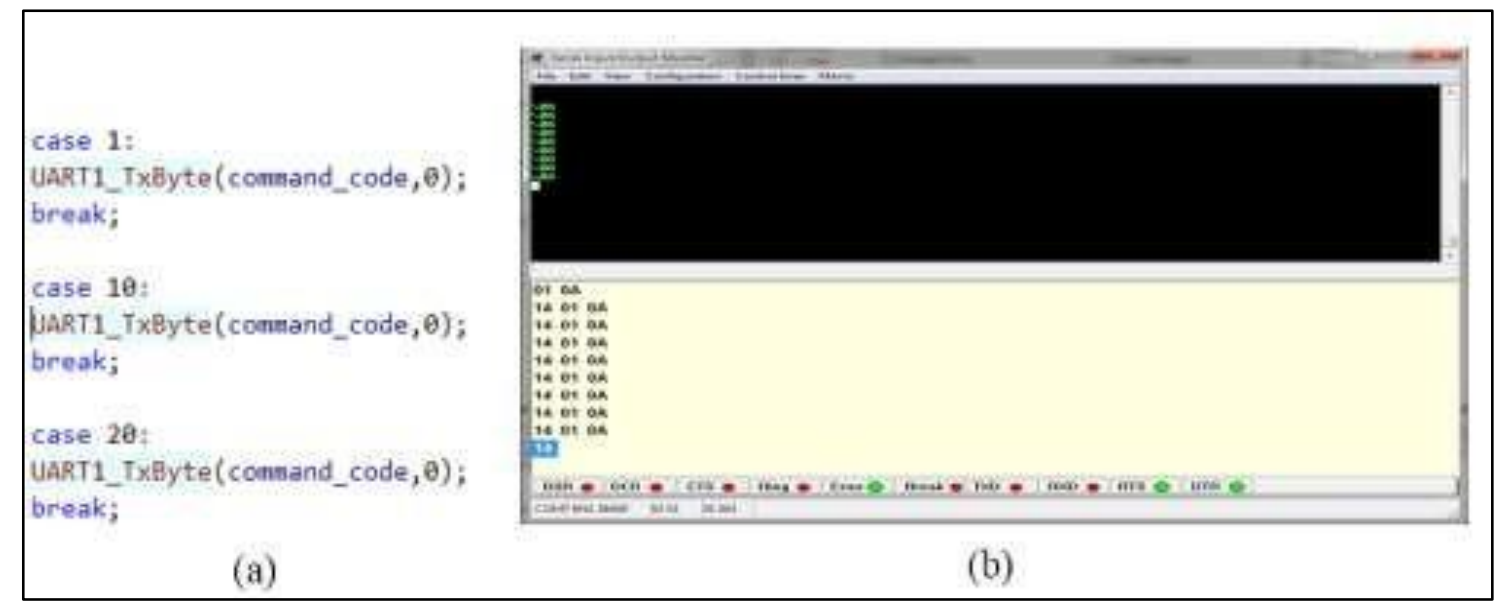

Gambar 12. Hasil Uji mode MPC (a) List kode fungsi untuk mengirim data, (b) hasil data dump serial line.

Gambar 12 (a) merupakan list kode perangkat lunak Master mengirimkan format berupa data dengan kode perintah 1 bermakna semua Piranti Slave yang terhubung pada jaringan komunikasi BUS melakukan pengukuran tiap sensor secara serentak. Kode perintah 10 bermakna slave \#1 mengirimkan data hasil pengukuran sensor setelah menerima kode perintah ini dan nilai 20 bermakna Slave \#2 mengirimkan data hasil pengukuran setelah menerima kode perintah ini. 
Pada masing-masing Slave dialokasikan 10 kode untuk keperluan yang lain. Hasil pengujian menunjukan bahwa tidak ada satu slave pun yang merespon kode perintah ini, hal ini dikarenakan perintah yang dikirimkan oleh Piranti Master berupa data bukan alamat perintah (register TX8B diset dengan nilai 0.) sehingga semua Piranti Slave mengabaikan format data tersebut seperti terlihat pada Gambar 12 (b).

Slave hanya merespon perintah yang diberikan oleh master jika kode format perintah tersebut berupa alamat atau dengan kata lain jika nilai register UCSRB untuk bit register TX8B bernilai 1.

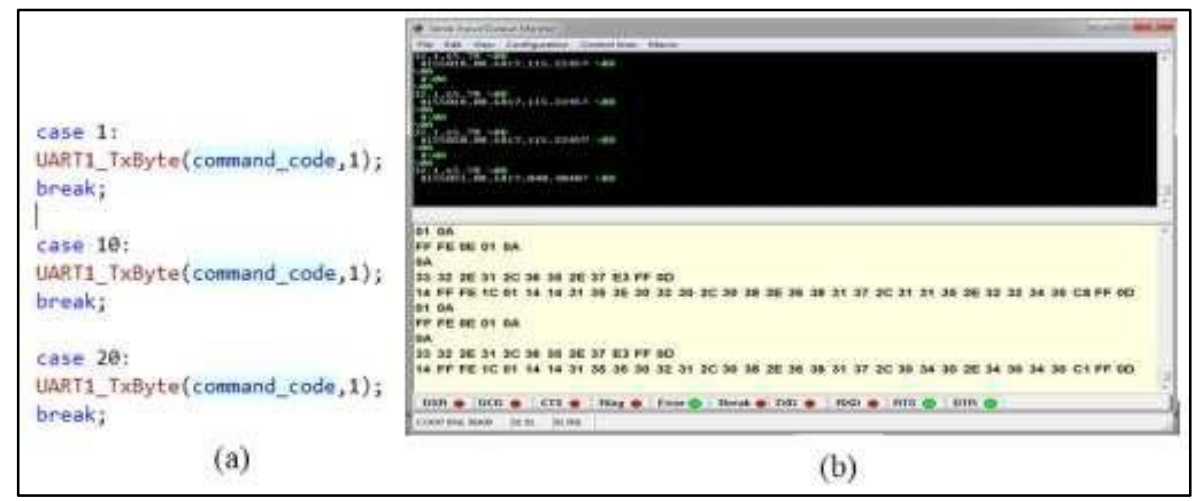

Gambar 13. Hasil Uji mode MPC (a) List kode fungsi untuk mengirim format alamat, (b) hasil data dump serial line

Gambar (a) merupakan list kode perangkat lunak Master mengirimkan format alamt. Gambar 13 (b) menunjukan nilai $01(\mathrm{H})$ atau 1 dalam desimal yang yang diartikan Piranti Master memerintahkan seluruh Piranti Slave untuk melakukan pengukuran sensor secara serantak. Perintah ini tidak memerlukan respon sehingga Slave tidak mengirimkan respon terhadap perintah tersebut tetapi langsung mangeksekusi perintah yang diberikan. Nilai berikutnya adalah $\mathrm{OA}(\mathrm{H})$ atau 10 dalam desimal, yang diartikan Master meminta Slave \#1 mengirimkan nilai hasil pengukuran yang telah dilakukan pada kode perintah 01. Format pesan ini memerlukan respon berupa data dari Slave sehingga pada pada dump serial line terlihat respon yang diberikan oleh slave berupa frame byte FFFE-0E-01-0A-0A-33-32-2E-31-2c-36-2E-37-E3- FF-0D sesuai dengan frame data protokol yang telah disepakati (menggunakan format hexa desimal).

Hasil integrasi modul sistem komunikasi data Perangkat Keras Master, Perangkat Keras Slave \#1 dan Slave \#2 seperti terlihat pada gambar 14[8]. Hasil integrasi sistem telah sesuai dengan desain perangkat keras dan perangkat lunak pada point 3 Dimana sistem telah mampu menampilkan hasil pengukuran dengan perubahan data hasil ukur sensor dengan durasi waktu satu detik.

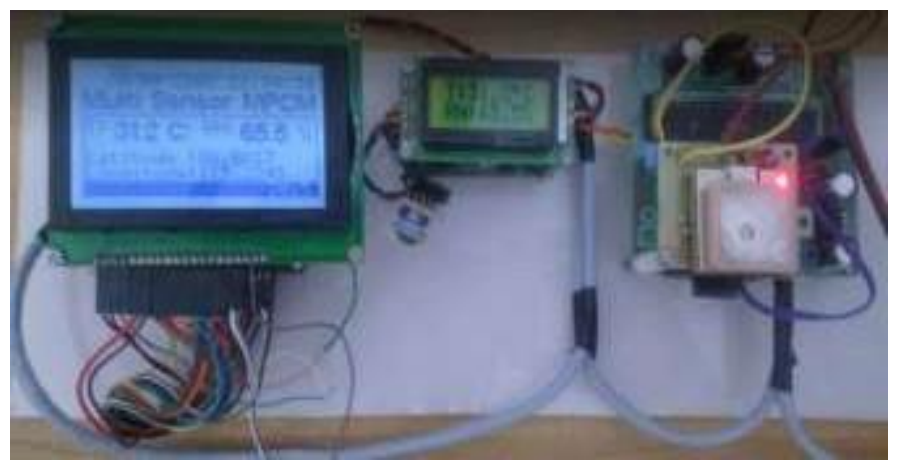

Gambar 14. Hasil Integrasi Sistem Komunikasi data mode MP

Modul Piranti Slave \#1 melakukan pengukuran temperatur lingkungan sebesar $31.2{ }^{\circ} \mathrm{C}$ dan kelembaban udara relatif dengan nilai ukur sebesar 65.5\%. Modul Piranti Slave \#2 mendapatkan nilai hasil ukur titik koordinat latitude -08.6817 dan longitude pada koordinat 
115.2245 untuk waktu pengukuran pada pukul 21:44:34 Wita.

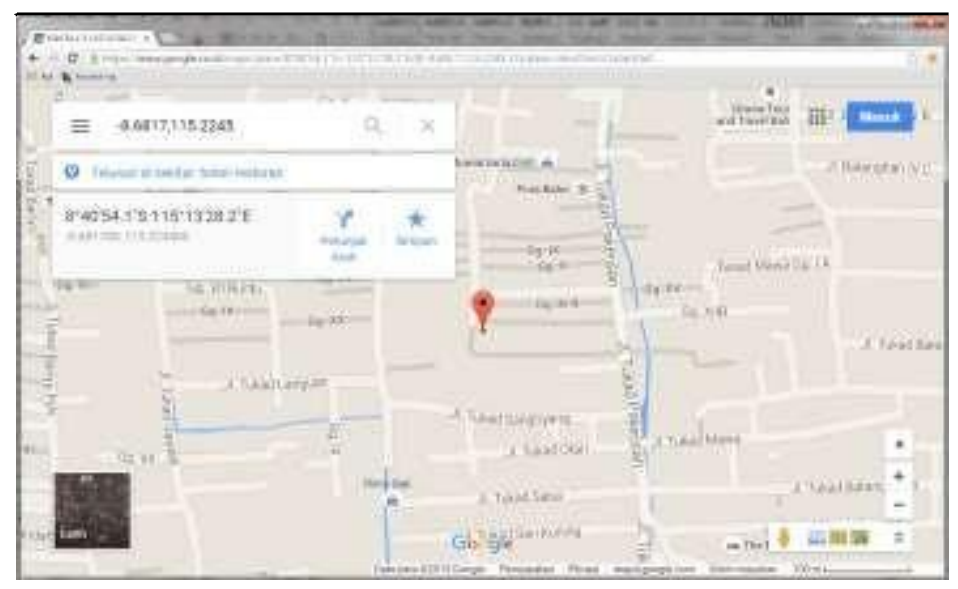

Gambar 15. Hasil Posisi Koordinat Pengukuran Menggunakan Bantuan Google Maps

Titik koordinat latitude dan longitude hasil pengukuran pada Piranti Slave \#2 jika diinputkan menggunakan bantuan Google Maps APl'S pada halaman website https://www.google.co.id/maps akan ditampilkan lokasi pengukuran berupa peta digital seperti terlihat pada Gambar 7. Ikon merah merupakan lokasi titik koordinat hasil ukur yang disajikan dalam bentuk peta digital dengan menggunakan bantuan Google Maps API'S. Hasil pengukuran yang disajikan masih mengalami offset sejauh \pm 3 Meter hal ini dipengaruhi oleh sensitifitas ukur dari sensor GPS yang dipergunakan.

\section{Kesimpulan}

Integrasi Modul Sistem Komunikasi Sensor Jamak dengan menggunakan satu buah Piranti Master dan dua buah piranti Slave untuk melakukan pengukuran temperatur lingkungan dan kelembaban udara relatif pada titik koordinat tertentu menggunakan bantuan GPS reciver sudah meunjukan hasil yang sesuai dengan rancangan awal penelitian. Sistem mampu melakukan pengukuran dalam selang waktu satu deik. Hasil uji yang dilakukan pada 360 data (360 detik) sistem bekerja dengan baik (tidak terdapat kesalahan data).

\section{Daftar Pustaka}

[1] T. P. M. Lock et al., "8-bit Microcontroller with 8K Bytes In-System Programmable Flash/ AT89S52," 2008.

[2] Atmel, "Atmel 8-Bit Microcontroller With 4/8/16/32Kbytes in-System Programmable Flash," 2014.

[3] G. P. S. E. Board, "GPS Engine Board SPECIFICATION."

[4] D. Hanto and B. Widiyatmoko, "Sistem Komunikasi Sensor Jamak Dengan Serial Rs 485," in Seminar Nasional Fisika 2012, 2011, pp. 187-195.

[5] Maxim, "RELIABILITY REPORT FOR MAX3082CPA+ PLASTIC ENCAPSULATED DEVICES," 2010.

[6] Maxim, "Low-Power, Slew-Rate-Limited RS-485/RS-422 Transceivers," 2003.

[7] A. Salam, Mukhidin, and T. Sucita, "Rancang Bangun Sistem Jaringan Multidrop Menggunakan RS-485 Pada Aplikasi Pengontrolan Alat Penerangan Kamar hotel," ELECTRANS, 2015.

[8] A. Tiyono, Sudjadi, and Setiawan, "Sistem Telekontrol SCADA Dengan Fungsi Dasar," Diponegoro University, 2011. 